
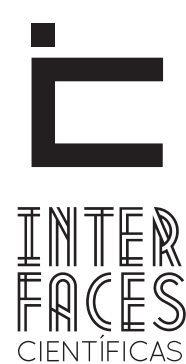

SAÚDE E AMBIENTE

ISSN IMPRESSO 2316-3313

ISSN ELETRÔNICO 2316-3798

\title{
ZOOPHARMACOGNOSY, THE SELF-MEDICATION BEHAVIOR OF ANIMALS
}

Eraldo Medeiros Costa-Neto ${ }^{1}$

\section{RESUMO}

Os animais podem fornecer bons indícios sobre novas fontes de remédios. Os pesquisadores têm observado diferentes espécies buscando e usando substâncias de modo a melhorar sua saúde. Este comportamento foi denominado de auto-medicação animal, ou zoofarmacognosia. Este artigo apresenta uma breve revisão sobre o tema e chama a atenção para estudos futuros, especialmente considerando a diversidade faunística brasileira.

\section{PALAVRAS-CHAVE}

Ecologia Química. Farmacologia. Etologia.

\section{ABSTRACT}

Animals can give good indications on new sources of medicine. Field researchers have observed different species of animals seeking and using substances in order to enhance their own health. This behavior was called as animal self-medication, or zoopharmacognosy. This article presents a brief review on the subject and calls attention for future field studies, especially considering Brazilian faunal diversity.

\section{KEYWORDS}

Chemical Ecology. Pharmacology. Ethology. 


\section{RESUMEN}

Los animales pueden dar buenas pistas sobre nuevas fuentes de medicamentos. Los investigadores han observado diferentes especies que buscan y el uso de sustancias para mejorar su salud. Este comportamiento se denomina auto-medicar a los animales o zoofarmacognosia. En este artículo se presenta una breve revisión

\section{INTRODUCTION}

When the problem is to discover new chemicals, it would be useful to observe wild animals (and domesticated ones too) as well as carrying out randomized prospection on rainforest plants, or interviewing indigenous peoples about their traditional healing knowledge and practices, since animals can give good indications about new sources of medicines (HUFFMAN; VITAZKOVA, 2007; MASI et al., 2011). According to primatologist Michael Huffman, "the probability that animals may have something to teach us about the medicinal use of plants is quite high" (BISER, 2006). Field researchers have observed different species of animals seeking and using substances in such a way as to enhance their own health. This behavior was called as animal self-medication.

In general, animal self-medication has been classified into two types: preventive (prophylactic - act of using nature's medicinal resources without any symptoms of infection or before infection), and curative (therapeutic - act of using nature's medicinal resources only after infection or illness). According to Huffman and Vitazkova (2007), the study of self-medication is devoted to understanding how animals respond to potential threats to their health and reproductive fitness and how these behaviors are maintained within a population. It is important to take into account that the scientific study of animal self-medication is sobre el tema y se apunta a futuros estudios, sobre todo teniendo en cuenta la diversidad de fauna en Brasil.

\section{PALABRAS CLAVE}

Ecología Química. Farmacología. Etología. not based on an assumption that animals possess an innate 'wisdom' by which they flawlessly know what is good for them. Instead, self-medication strategies are survival abilities honed by natural selection (ENGEL, 2005; HUFFMAN, 2001).

The term 'zoopharmacognosy', or the animal understanding of drugs, was readily applied to the great apes which appear to show an intention of purpose in their medication. In the beginning, this ethological phenomenon was linked to the eating habits of animals, and so it was considered as the study of the non-nutritional use of plants' pharmacoactive constituents by animals (RODRÍGUEZ; WRANGHAM, 1993). However, as stated by Engel (2002), it is often difficult to differentiate between behaviors that are nutritional and those that are medicinal, because the separation is 'artificial'. According to Huffman (1997), the basic premise of zoopharmacognosy is that animals utilize plant secondary compounds or other non-nutritional substances to medicate themselves.

Many carnivores, including dogs and cats, will now and again chew a particular plant species. For example, grass-eating stimulates either retching or the rapid expulsion of worms in diarrhea. This behavior, which often puzzles pet owners, may be an attempt to self-medicate against bacteria or perhaps parasi- 
tes. By following wild animals, especially those that are sick, field biologists have begun to draw up lists of plant species that may have healing properties of pharmaceutical interest (AMARAL et al., 1998; HUFFMAN et al., 1998a, 1998b; BEATTIE; ERHLICH, 2001). Bears, deer, elk, and various carnivores such as coyotes, foxes, and cougars have all been observed to seek out and consume specific plant species, and these observations have been interpreted as the use of medicinal plants by wild animals (Table 1). Whether or not watching animals will prove to be a useful method of discovering new medicinal plants remains to be seen (GOTTLIEB et al., 1996; GIBBS, 1996). It is worth mentioning that folk medicine culture is often alleged to have its roots in observations of animal behavior (MARTIUS, 1939), as many field researches point out that indigenous tribes and early peasants discovered the rudiments of their ethnomedicine in the healing plants sought out by sick animals (ENGEL, 2002).

As Johns and Duquette (1991) say, a pharmacophagous behavior uses non-nutrient components that are inevitably present in the diet in a beneficial way; in certain circumstances, obtaining these benefits becomes the primary reason for ingestion a substance. Chimpanzees, for instance, have been reported to consume several plant species containing sesquiterpene lactones for curative purposes (ROBLES et al., 1995). These authors have discussed recent in vivo antitumor studies with parthenin (isolated from Parthenium hysterophorus L.) and eupatoriopicrin (the principal sesquiterpene lactone in Eupatorium cannabinum L.), as well as the antiulcer activity of dehydroleucodin (isolated from Kaunia rufescens Lund ex De Candolle), and the cardiotonic activity of helenalin (Arnica montana L.).
Nutrients and toxins are encountered together in the diets of animals, and they interact to affect nutritional status. But how do animals acquire that habit? Individuals not only have to choose the correct plant, but they also have to know which parts of the plant to ingest and how to obtain them (BEKOFF, 2006). Naive individuals may have the empathic abilities to choose what they see others eat when they are sick. Infants have been observed to imitate their mothers immediately after they have fed on a particular medicinal plant. Naive apes may also try different foods when they are ill, and when they feel better they associate their improved health with a particular plant. Human infants regularly make these associations in the absence of knowing they are doing so (BEKOFF, 2006).

Notwithstanding, zoopharmacognosy is beyond the pharmacophagous behavior. It involves fur-rubbing and geophagy as well. The subject of self-medication in wild animals remains controversial because the evidence is mostly circumstantial or anecdotal, but there are many purported examples. Researchers from different scientific fields, such as animal behaviorists, ecologists, pharmacologists, anthropologists, geochemists, and parasitologists, are all exploring the possibility that many animal species use plants, soils, insects, and fungi as medicines in ways that guard against future illness (preventive medicine) and/or relieve unpleasant symptoms (curative medicine).

This article presents a brief review on the subject and calls attention for future field studies, especially considering Brazilian faunistic diversity.

\section{ANTI-PARASITES}

Reports of the highly unusual way that wild chimpanzees eat leaves from the genus Aspilia (Compo- sitae) provide the most convincing evidence for self-medication in a nonhuman animal. Janzen (apud 
HUFFMAN, 1997) was the first to suggest that the incidental ingestion of secondary plant compounds by non-human primates and other animals may help to combat parasites. In 1985, Eloy Rodríguez and Richard Wrangham showed that thiarubrine-A was the active chemical (against intestinal nematode parasites) in the Aspilia leaves that wild chimpanzees seek when they have upset stomachs (SEGELKEN, 2006). According to these authors, the queasy chimps pick Aspilia leaves and roll them around in their mouths, rather than chewing, before swallowing the capsule-like leaves whole. They swallow as many as 15-35 Aspilia leaves at a sitting, particularly in the rainy season when parasitic larvae abound and there is increased risk of infection (BISER, 2006). Aspilia also may have some anti-bacterial effect and is very useful against tumors. Chimpanzees have learned to distinguish between harmful plant parts and parts that contain beneficial compounds. This behavior is learned from other group members, which allows the group to benefit from the experience of an individual.

The fruits of Aframomum angustifolium (Sonn.) K. Schum. (Zingiberaceae) are commonly ingested by chimpanzees, bonobos, and gorillas across Africa (HUFFMAN, 1997). Laboratory assays of homogenized fruit and seed extracts show significant anti-microbial activity.

Along with whole leaf-swallowing, bitter leaf-chewing is another method to get rid of parasites. It was noted that infection of parasites drops noticeably after chewing leaves of pith (Vernonia amyddali- na Del., Compositae). Chemical analysis has revealed sesquiterpene lactones and new steroid glucosides with antiparasitic activity against Schistosoma, Plasmodium and Leishmania (HUFFMAN et al., 1996; JACOBS, 2006). This plant is not consumed at a regular basis by chimpanzees, but when it is eaten, it is often in small amount by those apes that appear ill (BISER, 2006). V. amygdalina has more than 25 known medicinal uses among the peoples of sub-Saharan Africa, about half of them for intestinal and parasitic ailments. As Huffman (1997) points out, the noted recovery time of 20-24 hours after bitter-pith chewing in chimpanzees is comparable to that of local human inhabitants, the Tongwe, who use cold concoctions of this plant as a treatment for intestinal parasites, diarrhea, and stomachaches. Indeed, the sesquiterpene lactones present in this species and a number of other Vernonia species are well known for their anthelmintic, antiamoebic, antitumor, and antibiotic properties.

The anubis baboons (Papio anubis Lesson, 1827) and hamadryas baboons (Papio hamadryas Linnaeus, 1758) in Ethiopia use fruits and leaves of Balanites aegyptiaca Del. to control schistosomiasis (RAMAN; KANDULA, 2008). Its fruits contain diosgenin, a hormone precursor which presumably hinders the development of schistosomes (LOZANO, 1998).

Indeed, antiparasitic behavior occurs in animals ranging from arthropods to primates, and is undoubtedly the product of a long evolutionary process ( $\mathrm{HU}$ FFMAN; VITAZKOVA, 2007).

\section{REPRODUCTIVE REMEDIES}

Female muriqui monkeys (Brachyteles arachnoides É. Geoffroy, 1806) from Brazil, just before the mating period, prepare themselves to that occasion by eating the leaves of Apuleia leiocarpa (Vog.) JF Macbr. and Platypodium elegans Vog., and the fruits of Enterolobi- um contortisiliquim (Vell.) Morong. The first two plants contain isoflavanoids, which are compounds similar to estrogen. These chemicals may increase estrogen levels in the body, thereby decreasing fertility. The latter plant contains a precursor to progesterone called stig- 
masterol, which increases the monkey's chance of becoming pregnant (BISER, 2006). Another amazing finding involves the possible influence of diet on the sex of offspring among Costa Rican mantled howler monkeys (Alouatta palliata Gray, 1849).

\section{FUR-RUBBING}

A great number of animals seem to have found techniques to get rid of external parasites by rubbing substances on their skin or line their nests with them (BONALUME NETO, 1993). On the southeastern edge of the Nicoya Peninsula, Costa Rica, white-faced capuchin monkeys (Cebus capucinus Linnaeus 1758) break open the fruits of certain species of Citrus and rub the pulp and juice into their fur (BAKER, 1996, 1997). They also tear stems, leaves, and seed pods from Clematis dioica L., Piper marginatum Jacq., and Sloanea terniflorastems, respectively. They mix these pungent plants with saliva and vigorously rub them in as well. Native people use three of the plant genera they select - Citrus, Clematis, and Piper - to treat skin irritations or repel insects.

North American brown bears (Ursos arctos Linneaus, 1758) reportedly make a past of osha roots ( $L i$ gusticum porteri Coulter and Rose, Umbelliferae) and saliva, running it through their fur to repel insects or soothe bites. This plant, locally known as bear root, contains 105 active compounds, such as coumarins that may repel insects when topically applied. Navajo Indians are said to have learned to use this root medicinally from the bear for treating stomachaches and infections (BISER, 2006). As the ethnobotanist Sigstedt says, "I learned from them (American Indians) the legend that the bear, a generous divine being in their tradition, gave them osha a gift - a medicinal plant of great importance" (ANDREWS, 2005). American Indigenous communities who live close to the plant's natural habitat use its root as a headache remedy, as
African elephants (Loxodonta africana Blumenbach, 1797) seek a particular tree of the Boraginaceae family, possibly to induce labor. In addition, Kenyan women brew a tea from the leaves of this tree to induce labor (BISER, 2006).

a fungicide, as an insecticide, and for numerous other complaints (ANDREWS, 2005). Sigstedt argues that "the Native Americans were such excellent scientific observers that they were aware that the bear was using the plant, and they were probably scientifically accurate when they included these observations in their stories".

White-nosed coatis (Nasua narica Linnaeus, 1766) of Barro Colorado Island in Panama take the menthollike smelling resin from freshly scraped bark of Trattinnickia aspera (Swart) (Burseraceae) and vigorously rub it into their own fur and/or that of conspecifics in order to kill ectoparasites such as fleas, ticks, and lice, as well as biting insects such as mosquitoes (HUFFMAN, 1997). A chemical study of the resin has revealed the presence of the triterpenes $\alpha$ - and $\beta$-amyrin, the eudesmane derivative $\beta$-selinene, and the sesquiterpene lactone $8 \beta$-hydroxyasterolide (ROBLES et al.,1995).

More than 200 species of song birds wipe ants through their plumage (ENGEL, 2005). Birds take ants in their bill and wipe them vigorously along the spine of each feather down to the base. Other times they roll in ant hills twisting and turning to allow the ants to crawl through their feathers. The most commonly ants used by birds are those which spray formic acid. In laboratory tests, this acid is harmful to feather lice. Its vapor alone is enough to kill them. According to the biologist Larry Clark, European starlings (Sturnus vulgaris Linnaeus, 1758) protect themselves from a 
myriad of possible infections by lining their nests with select fresh plants (BISER, 2006). Wild carrot (Dauscus carota L.), for example, contains the steroid Bsitosterol, a compound that repels mites and inhibits their egg-laying abilities. This compound is also found in leaves of the margosa tree (Azadirachta indica A. Juss.), from which house sparrows (Passer domesticus Linnaeus, 1758) often gather material to line their nests, and which some Native Americans employ as a tick repellent. These birds have also been observed to change from neem to quinine-rich leaves of Krishnachua tree (Caesalpinia pulcherrima [L.]Sw.) during an outbreak of malaria. Quinine controls the symp- toms of malaria and scientists wonder whether the sparrows were selecting leaves to deal with malarial symptoms (ROUNAK et al., 2011).

Although anting was first recorded in birds, ant nests are also sought by squirrels, cats, and monkeys who roll in them for similar relief (HAUSER, 1964). According to Zito et al. (2003), owl monkeys (Aotusspp.) rub highly toxic millipede secretions into their bodies during the humid wet season when insect bites (particularly mosquito bites) are ferocious. These secretions contain powerful insect repellents called benzoquinones. Birkinshaw (1999) reports the use of millipedes by black lemurs.

\section{GEOPHAGY}

Geophagy can be understood as a component of the pharmacophagous behavior of animals that is the basis for the phenomenon of medicine that is essential to all human cultures (JOHNS; DUQUETTE, 1991). Macaws, parrots, tapirs, forest elephants, colobus monkeys, mountain gorillas, chimpanzees, as well as many human beings seek out and eat clay, which absorbs intestinal bacteria and their toxins and alleviates stomach upset and diarrhea (BOLTON et al. 1998). Kaopectate ${ }^{\mathrm{TM}}$, a pharmaceutical commercially sold to treat gastrointestinal upset and other intestinal ailments, uses a type of clay as its active ingredient (WILLIAM et al., 2000).

Red colobus monkeys (Procolobus pennantii kirkii Waterhouse, 1838) on Zanzibar Island, Tanzania, prefer leaves of the exotic Indian almond and mango trees, which leaves are high in protein as well as are high in secondary compounds called phenols. These substances interfere with the monkeys' digestion. They counteract the toxicity of the leaves by consuming charcoal from charred stumps, logs, branches, and from human kilns (STRUHSAKER et al. 1997). It was known later that charcoal had a high adsorptive capacity for phenols. Although charcoal eating is relatively rare, soil consumption, or geophagy, occurs widely among many primates (MAHANEY et al. 1996; MUELLER, 1996; KNEZEVICH, 1998). Clay and charcoal have large adsorptive surface areas enabling them to buffer the stomach against toxic compounds. Worldwide, people also use charcoal to inactivate lethal substances and prevent intestinal infections (BISER, 2006).

South American mantled howler monkeys ( $A$. palliata) appear not to suffer from tooth decay. Their diet is low in sugar and includes large numbers of cashews, which are high in phenols and known to inhibit the bacteria most responsible for tooth decay. 


\section{ANTIVENOMS}

In Brazilian folklore peasant communities tell about how some lizard species fight against venomous snakes and beat them without suffering from their venom. According to these anecdotal accounts, lizards such as Tupinambis spp. (Portuguese: teiú) go for a particular root (teiú's root) every time they are bitten by the snake, and come back to fight against it until they kill it. Amongst the herbal species listed in these folk stories, we have Jatropha elliptica M. Arg (Euphorbiaceae). People use this plant as medicine for the treatment of snakebites, rheumatism, venereal diseases, as well as anti-inflammatory, fortifier, and anti-syphilis (Silva et al., 1998).

\section{GETTING HIGH}

Animals other than ourselves also seem inclined to ingest, and overingest, foods with mind-bending properties (ENGEL, 2002). This author says, for instance, that the ancient Mayans are thought to have stumbled onto a powerful narcotic by watching bees. But we are alone in treating plants to rid them of secondary compounds. We are the only animals to boil, dry, bake, microwa-

\section{IN CONCLUSION}

Further exploration in the field of zoopharmacognosy would teach us more about behavior, botany, and medicine, all areas in which we may apply our knowledge to benefit future generations - but without wildlife or habitats, there will be little to study (BISER, 2006). Three of the greatest constraints on field investigations of self-medicative behavior are 1) the
Pliny the Older has already recorded the use of herbs by some lizards when they fight with snakes (MARIA Y CAMPOS, 1979).

A folkloric story from India tells about how the medicinal use of a local plant was discovered. According to this folk wisdom, a red-wattled lapwing (Vanellus indicus Boddaert, 1783) drove away a venomous snake, which was after its nest, throwing small twigs towards it. Gradually the snake lowered its head and retreated. A woman who was passing by realized that the twigs were taken from Indoneeasiella echioides (L.) Screem. (Acanthaceae). Thus the antiophidic use of this plant was discovered (TOPNO, 1999).

ve, soak, and otherwise process plant to enhance their edibility. We are the only cooks on the planet! (ALLPORT, 2000).

For this reason, modern human diets lack both the amount and the diversity of several medicinal plant compounds, many of which have been largely bred out of our domesticated food plants. unpredictability of the behaviors' occurrence, 2) unreliability of being able to consistently follow and observe sick individuals over time, and 3) restraints on experimental manipulation (HUFFMAN, 1997).

As Huffman (2003) stands out, "Phytochemical studies have demonstrated a wide array of biologi- 
cally-active properties in this medicinal plant species. In light of the growing resistance of parasites and pathogens to synthetic drugs, the study of animal self-medication and ethno-medicine offers a novel line of investigation to provide ecologically-sound methods for the treatment of parasites using plant-based medicines in populations and their livestock living in the tropics".

Since Brazil presents a huge diversity in animal species, we should expect good indications of new potential drugs from their self-medication behavior. In this regard the study of pharmacophagous habits is supposed to be thought as a significant research area in order to fill the blank in our knowledge on the use of natural medicinal substances by animals.

Furthermore, the material here presented aims to give a contribution for a wider and more critical discussion on the conservation biology, health public policies, sustainable management of natural resources, bioprospection, and patents.

\section{REFERENCES}

ALLPORT, S. The primal feast: food, sex, foraging, and love. New York: Harmony Books, 2000. 260 p.

AMARAL, L.F.G.; MENSOR, L.L.; LEITÃO, G.G.; LEITÃO, S.G.; FLORIANO, N.C.N.; GARCIA, V.L.; MENEZES, F.S. Phenolics contents $x$ antioxidant activity: a study on plants eaten by group of howling monkeys (Alouatta fusca). In: TANNIN CONFERENCE, 3., v. 1, 1998, Oregon. Abstracts... Oregon: Bend, 1998. p. 157-159.

ANDREWS, R. Western science learns from native culture. Available at: http://www.the-scientisi.com/yr1992/ march/andrews_p6_920316.html. Accessed in Oct 2005.

BAKER, M. Fur rubbing: use of medicinal plants by capuchin monkeys (Cebus capucinus). American Journal of Primatology, New York, v. 38, p. 263-270, 1996.

BAKER, M. Identification and selection of fur rubbing materials by white-faced capuchin monkeys (Cebus capucinus). American Journal of Primatology, New York, v. 42, p. 93, 1997.

BEATTIE, A.; ERHLICH, P.R. Wild solutions: how biodiversity is money in the bank. Yale: Yale University Press, 2001. 256 p.
BEKOFF, M. Self-medication in primates. Available at: http://www.bouldernews.com/science/bekoff/17lsci. html. Accessed in Feb 2006

BIRKINSHAW, C.R. Use of millipedes by black lemurs to anoint their bodies. Folia Primatologica, Basileia (Suíça), v. 70, p. 170-171, 1999.

BISER, J.A. Really wild remedies. Available at: http:// nationalzoo.si.edu/publications/zoogoer/1998/1/reallywildremedies.cfm. Accessed in Mar 2006.

BOLTON, K.A.; CAMPBELL, V.M.; BURTON, F.D. Chemical analysis of soil of Kowloon (Hong Kong) eaten by hybrid macaques. Journal of Chemical Ecology, Londres, v. 24, p. 195-205, 1998.

BONALUME NETO, R. Animais ensinam medicina. FoIha de São Paulo, Caderno 6, p. 18, 2 maio 1993.

BROWN, K.S. Jr. Insetos aposemáticos: indicadores naturais de plantas medicinais. Ciência e Cultura, Rio de Janeiro, v. 32 (Supl.), p. 189-200, 1979.

ENGEL, C. Wild health: how animals keep themselves well and what we can learn from them. New York: 
Houghton Mufflin Company, 2002. 276 p.

ENGEL, C. Animal self-medication. Available at: http://www.animalselfmedication.com. Accessed in Feb 2005.

GIBBS, W.W. Jungle medicine. Scientific American, New York, v. 275, p. 20, 1996.

GOTTLIEB, O.R.; BORIN, M.R. DE M.B.; BOSISIO, B.M. Trends of plant use by humans and nonhuman primates in Amazonia. American Journal of Primatology, New York, v. 40, p. 189-195, 1996.

HAUSER, D.C. Anting by gray squirrels. Journal of Mammalogy, Lawrence (USA), v. 45, p. 136-138, 1964.

HUFFMAN, M.A. Current evidence for self-medication in primates: a multidisciplinary perspective. Yearbook of Physical Anthropology, Saint Louis, v. 40, p. 171200, 1997.

HUFFMAN, M.A. Self-medicative behavior in the African great apes: an evolutionary perspective in the origins of human traditional medicine. Bioscience, Berkeley, v. 51, p. 651-661, 2001.

Huffman, M.A. Animal self-medication and ethno-medicine: exploration and exploitation of the medicinal properties of plants. Proceedings of Nutrition Society, Cambridge, v. 62, p. 371-381, 2003.

HUFFMAN, M.A.; KOSHIMIZU, K.; OHIGASHI, H. Ethnobotany and zoopharmacognosy of Vernonia amygdalina, a medicinal plant used by humans and chimpanzees. In: CALIGARI, P.D.S.; HIND, D.J.N. (ed.). Compositae: biology and utilization, v. 2. London: Royal Botanic Gardens, 1996. p. 351-360.

HUFFMAN, M.A., ELIAS, R., BALANSARD, G., OHIGASHI, H. NANSEN, P. Self-medication in the great apes: a multidisciplinary study of behavior, diet, and health. Pimatologie, Paris, v. 1, p. 179-204, 1998a.
HUFFMAN, M.A.; OHIGASHI, H.; KAWANAKA, M.; PAGE, J.E.; KIRBY, G.C.; GASQUET, M.; MURAKAMI, A.; KOSHIMIZU, K. African great apes self-medication: a new paradigm for treating parasite disease with new medicines. In: AGETA, H (Ed.). Towards natural medicine research in the $\mathbf{2 1}^{\text {st }}$ century. New York: Elsevier, 1998b, p. 113-123.

HUFFMAN, M.A.; VITAZKOVA, S.K. Primates, plants, and parasites: theevolution of animal self-medication and ethnomedicine. In: ELISABETSKY, E.; ETKIN, N.L. (Ed.). Ethnopharmacology, e-book http://www.eolss. net. Oxford: Eolss Publishers, 2007.

JACOBS, J.Q. A comparison of some similar chimpanzee and human behaviors. Available at: http://www. jqjacobs.net/anthro/paleo/primates.html.2006. Accessed in Feb 2005.

JOHNS, T.; DUQUETTE, M. Detoxification and mineral supplementation as functions of geophagy. The American Journal of Clinical Nutrition, Bethesda (EUA), v. 53, p. 448-456, 1991.

KNEZEVICH, M. Geophagy as a therapeutic mediator of endoparasitism in a free-ranging group of rhesus macaques (Macaca mulatta). American Journal of Primatology, New York, v. 44, p. 71-82, 1998.

LISONBEE, L. D.; VILLALBA, J. J.; PROVENZA, F. D.; HALL, J. O. TANNINS AND SELF-MEDICATION: IMPLICATIONS FOR SUSTAINABLE PARASITE CONTROL IN HERBIVORES. Behav. Processes, v. 82, p. 184-189, 2009.

LOZANO, G. A. Parasitic stress and self-medication in wild animals. Advances in the Study of Behavior, London, v. 27, p. 291-317, 1998.

MAHANEY, W.C.; HANCOCK, R.G.V.; AUFREITER, S.; HUFFMAN, M.A. Geochemistry and clay mineralogy of termite mound soil and the role of geophagy in chimpanzees of the Mahale Mountains, Tanzania. Primates, Londres, v. 37, p. 121-134, 1996. 
MARTIUS, C.F.P. von. Natureza, doenças, medicina e remédios dos índios brasileiros (1844). São Paulo: Companhia Editora Nacional, 1939. 183 p.

MASI, S.; GUSTAFSSON, E.; JALME, M. S.; NARAT, V.; TODD, A.; BOMSEL, M.C.; KRIEF, S. Unusual feeding behavior in wild great apes, a window to understand origins of self-medication in humans: Role of sociality and physiology on learning process. Physiology and Behavior, London, v. 105, p. 337-349, 2011.

MUELLER, K.-H. Primate geophagy and its significance in captive care: a survey. Der Zoologische Garten, Berlin, v. 66, p. 53-62, 1996.

RAMAN, R.; KANDULA, S. Zoopharmacognosy: selfmedication in wild animals. Resonance, Bangalore, v. 13, p. 245-253, 2008.

ROBLES, M.; AREGULLIN, M.; WEST, J.; RODRIGUEZ, $E$. Recent studies on the zoopharmacognosy, pharmacology and neurotoxicology of sesquiterpene lactones. Planta Medica, New York, v. 61, p. 199-203, 1995.

RODRÍGUEZ, E.; WRANGHAM, R. Zoopharmacognosy: the use of medicinal plants by animals. Recent Advances in Phytochemistry, Londres, v. 27, p. 89-105, 1993.

ROUNAK, S.; APOORVA, K.; SHWETA, A. Zoopharmacognosy (animal self medication): A review. International Journal of Research in Ayurveda \& Pharmacy, Karnataka, v. 2, p. 1510-1512, 2001.
SEGELKEN, R. 2006. Mountain gorilla diet could yield health secrets of impenetrable forest's salad bar. Available at: http://www.news.cornell.edu/releases/Sept96/gorilla.hrs.html. Accessed in Feb 2005.

SILVA, S.M.P.; SILVA, A.M.; COELHO, M.F.B. Aspectos etnoecológios de purga de lagarto (Jatropha elliptica M. Arg. - Euphorbiaceae) na baixada cuiabana, Mato Grosso, Brasil. In: SIMPÓSIO BRASILEIRO DE ETNOBIOLOGIA E ETNOECOLOGIA 2., Resumos... São Carlos: UFScar, 1998, p. 20.

STRUHSAKER, T.T.; COONEY, D.O.; SIEX, K.S. Charcoal consumption by Zanzibar red colobus monkeys: its function and its ecological and demographic consequences. International Journal of Primatology, Washington, DC, v. 18, p. 61-72, 1997.

TAUNAY A DE E. Monstros e monstrengos do Brasil. Revista do Museu Paulista, São Paulo, v. 21, p. 9111048, 1937.

TOPNO, S. Birds and animals' herbal wisdom. Honey Bee, Vastrapur, n. 10, p. 18-19, 1999.

William, C.M.; Michael, W.M.; Mulyono, H.; Hancock, R.G.V.; Aufreiter, S.; Reich, M.; Wink, M. Mineral and chemical analyses of soils eaten by humans in Indonesia. International Journal of Environmental Health Research, Oxford, v. 10, p. 93-109, 2000.

ZITO, M.; EVANS, S.; WELDON, P.J. Owl monkeys (Aotus spp.) self-anoint with plants and millipedes. Folia Primatologica, Basileia (Suíça), v. 74, p. 159-161, 2003. 
Table 1. Some examples of wild animals with reported self-medication behavior.

\begin{tabular}{|c|c|c|}
\hline Animal species & Source of remedy & Indication \\
\hline Baboon & Balonites spp. fruits & Against schistosomosis \\
\hline \multicolumn{3}{|l|}{ Papio hamadryas Linnaeus, 1758} \\
\hline Chimpanzee & Aspilia spp. leaves & $\begin{array}{l}\text { It contains antimicrobials that act } \\
\text { against fungi and bacteria }\end{array}$ \\
\hline \multirow[t]{6}{*}{ Pan troglodytes Blumenbach, 1799} & & $\begin{array}{l}\text { Anti-parasite and for digestive sys- } \\
\text { tem }\end{array}$ \\
\hline & Vernonia spp. leaves & \\
\hline & & Used for intestinal disorders \\
\hline & Lippea picata leaves & \\
\hline & Ficus exasperata Vahl. leaves & Anti-microbial (bacteria and fungi) \\
\hline & Commelinassp. leaves & Anti-microbial of general use \\
\hline European starling & Several volatile vegetation & Anti-parasite \\
\hline \multicolumn{3}{|l|}{ Sturnus vulgaris Linnaeus, 1758} \\
\hline Mountain gorilla & Aframomum angustifolium fruits & Antibiotic \\
\hline \multicolumn{3}{|l|}{$\begin{array}{l}\text { Gorilla gorilla beringei (Matschie, } \\
\text { 1903) }\end{array}$} \\
\hline Ursina howler monkey & Unknown plants & Birth control and sex ratio choice \\
\hline \multicolumn{3}{|l|}{ Alouatta ursine (Humboldt, 1815) } \\
\hline \multirow[t]{2}{*}{ Reindeer } & Amanita muscaria & \\
\hline & (L. ex fr.) Hooker & Inebriant \\
\hline \multicolumn{3}{|l|}{ Rangifer tarandus Linnaeus, 1758} \\
\hline Brown bear & Ligusticum porteri root & Against external parasites \\
\hline \multicolumn{3}{|l|}{ Ursus arctos (Linnaeus, 1758) } \\
\hline Sloth bear & Madhuca spp. flowers & Inebriant \\
\hline Melursus ursinus (Shaw, 1791) & & \\
\hline
\end{tabular}


Recebido em: 25 de junho de 2012

Avaliado em: 25 de julho de 2012

Aceito em: 13 de agosto de 2012
1 Doutor em Ecologia e Recursos Naturais. Docente do Departamento de Ciências Biológicas. Universidade Estadual de Feira de Santana - UEFS.

E-mail: eraldont@hotmail.com 